\title{
COVID 19 - Possible interrelations with respiratory comorbidities caused by occupational exposure to various hazardous bioaerosols. Part I. Occurrence, epidemiology and presumed origin of the pandemic
}

\author{
Jacek Dutkiewicz ${ }^{1, A-F \oplus}$, Barbara Mackiewicz ${ }^{2, A, C-E \oplus}$, Marta Kinga Lemieszek $^{3, A-F} \oplus$ \\ ${ }^{1}$ Department of Biological Health Hazards and Parasitology, Institute of Rural Heath, Lublin, Poland \\ 2 Department of Pneumonology, Oncology and Allergology, Medical University, Lublin, Poland \\ ${ }^{3}$ Department of Medical Biology, Institute of Rural Heath, Lublin, Poland \\ A - Research concept and design, B - Collection and/or assembly of data, C - Data analysis and interpretation, \\ $D$ - Writing the article, E - Critical revision of the article, $F$ - Final approval of article \\ Dutkiewicz J, Mackiewicz B, Lemieszek MK. COVID 19: Possible interrelations with respiratory comorbidities caused by occupational exposure \\ to various hazardous bioaerosols. Part I. Occurrence, epidemiology and presumed origin of the pandemic. Ann Agric Environ Med. 2020; \\ 27(4): 491-504. doi: 10.26444/aaem/130871
}

\section{Abstract}

The occupational bioaerosols containing viruses, bacteria, fungi, microbial toxins and plant or animal particles, may evoke infectious, allergic or immunotoxic diseases which may co-exist as comorbidities with COVID-19 and exacerbate the course of disease. They include hypersensitivity pneumonitis (HP) caused mostly by bacteria, fungi, and particles containing animal proteins, and immunotoxic diseases such as organic dust toxic syndrome (ODTS) and byssinosis, caused mostly by bacterial and fungal toxins. The two most probable scenarios of possible interrelations between these three comorbidities (CM) and COVID-19 are: 1) 'Triggering' - when infection with SARS-CoV-2 triggers severe CM after bioaerosol exposure; 2) 'Reverse triggering' when exposure to bioaerosol exacerbates a symptomless or mild course of COVID-19, and evokes a severe disease. The occupations mostly endangered by COVID-19 as the result of exposure to SARS-CoV-2 bioaerosol, or to other bioaerosols which may exacerbate this disease, include: health care workers, social workers, breeders of fur animals, slaughterhouse workers, workers engaged in the processing and selling of seafood, and probably also agricultural workers, mainly in the developing countries. The authors present a hypothesis for the origin of the present pandemic. It assumes that a mild form of the present SARS-CoV-2 that is supposedly circulating among the Chinese population in the eastern part of the country, mutated under the influence of as yet unknown factor(s) present in the Chinese seafood markets, probably component(s) of bioaerosols, into the virulent and highly contagious form, known as the present SARS-CoV-2, under a scenario similar to that the authors have named 'Reverse triggering'.

\section{Key words}

allergens, byssinosis, occupational exposure, bioaerosols, endotoxin, comorbidities, ODTS, COVID-19, SARS-CoV-2, hypersensitivity pneumonitis

\section{INTRODUCTION}

Pathogen and disease. The disease COVID-19 is caused by coronavirus named SARS-CoV-2, measuring 60-140 nm (Fig. 1). This is an enveloped virus that contains a positivesense single-stranded RNA genome with a size of $29.9 \mathrm{~kb}$ and a nucleocapsid of helical symmetry [1-3]. Its envelope is covered with numerous spikes 9-12 nm long, resembling a solar crown (Latin: corona) for which the entire Coronaviridae family was named (Fig. 2). The spikes contain in their upper parts glycoprotein S-1 that binds to the ACE2 (angiotensinconverting enzyme 2) on the surface of host cells, while type II transmembrane serine protease (TMPRSS2) and glycoprotein S-2 (located in lower parts of spikes) enable virus entry into these cells $[1,2]$.

SARS-CoV-2 emerged in December 2019 in the Huanan Seafood Wholesale Market located in Wuhan, China [4],

\footnotetext{
Address for correspondence: Jacek Dutkiewicz, Department of Biological Health Hazards and Parasitology, Institute of Rural Health, Jaczewskiego 2, 20-090 Lublin, Poland

E-mail: jadut777@onet.eu

Received: 06.11.2020; accepted: 25.11.2020; first published: 08.12.2020
}

although the origin of this outbreak has so far not been determined until now. Since then, COVID-19 has devastated the world population, causing over 64 million human infections and over 1.5 million deaths worldwide, data as of 3 December 2020.

It is estimated that about $80 \%$ of the people infected with SARS-CoV-2 are asymptomatic or show mild or moderate illness, mostly restricted to the upper and conducting airways $[1,5]$. In the remaining $20 \%$ of patients, the disease is severe and usually manifests as interstitial pneumonia which may lead to acute respiratory distress syndrome (ARDS) and death $[1,2]$.

Risk factors. The most important risks of severe COVID-19 illness are associated with some pre-existing chronic conditions, such as hypertension, diabetes mellitus and cardiovascular or cerebrovascular diseases. Other important risk factors are: age above 60 years, obesity, history of cigarette smoking, chronic renal disease, chronic obstructive pulmonary disease, immunodeficiency, and cancer $[1,6-8]$. Some authors consider that occupational exposure to some environmental factors, such as dusts (silica dust, asbestos, 




Figure 1. Transmission electron microscopic image of an SARS-CoV-2 isolate from the first US case of COVID. The spherical extracellular viral particles contain crosssections through the viral genome, seen as black dots, $\times 65,000$.

Source: Centers for Disease Control and Prevention, USA.

Authors: Cynthia S. Goldsmith and A. Tamin, Public Health Image Library \# 23336

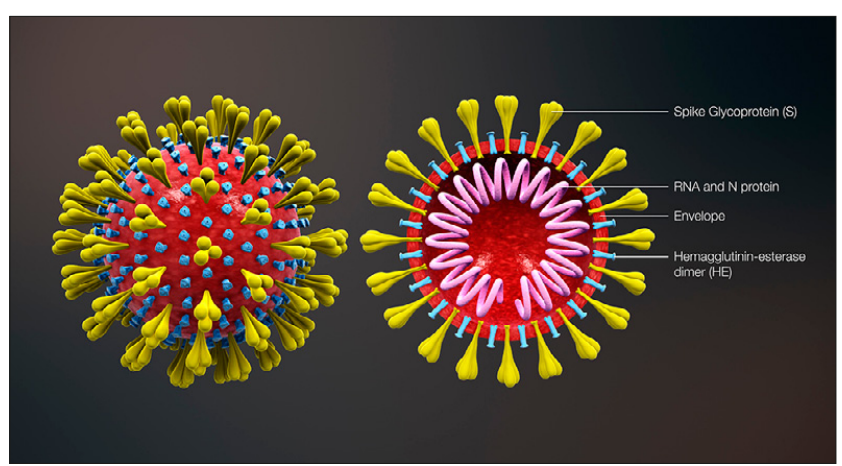

Figure 2. Spatial structure of the SARS-CoV-2 particle.

Source: Scientific Animations, USA. https://www.scientificanimations.com/imagegallery

coal dust), fumes and gases or uncomfortable microclimate (e.g. low temperature, high humidity) may also be associated with a risk of severe COVID-19 disease [3, 9].

Until recently, scant attention with respect to COVID-19 risk has been paid to heterogeneous bioaerosols (other than SARS-CoV-2), as well as to the diseases they cause, which may co-exist with COVID-19 (as comorbidities) and largely influence its course. In the current study, the authors provide a concise characterization of the most important bioaerosols occurring in occupational environments and the diseases they evoke.

\section{BIOAEROSOLS}

General characteristics. Bioaerosols are suspensions of biological particles in the air that occur by the emission into air fine particles of organic fluids, forming droplet aerosols, or fine particles of organic solid substances, forming dust aerosols. They are emitted into air mostly by the industrial processing of various materials, by treatment of waste and sewage, and by the living processes of plants, animals and humans. Exposure to bioaerosol inhalation is mainly occupational and occurs mostly in agricultural settings. The examples of adverse dusts composed of biological particles that occur in this environment could be grain dust or dusts in animal houses, such as cow barns or piggeries. Dust concentrations in dwellings are much lower compared to working environments, and the most important bioaerosol occurring therein is called 'house dust' $[10,11]$.

Bioaerosols could be of microbial, plant and animal origin. In real life, however, bioaerosols containing only one kind of particles are rare, they are usually mixtures of various kinds of particles. For example, grain dust may contain as predominant constituents bacteria, endotoxin, fungi, $\beta$-glucan, fragments of seeds and particles of faeces and bodies of the mites and insects feeding on grain, whereas dust that occurs in cow barns may contain bacteria, endotoxin, particles of hay and other fodders, as well as particles of cow epithelia, hair and faeces. The 'house dust', occurring in dwellings, contains bacteria, fungi, particles of human epithelium and hairs, as well as particles of faeces and bodies of mites feeding on human epithelium [11].

Components. The main components of bioaerosols are: viruses, bacteria, endotoxin, peptidoglycan, fungi, $\beta$-glucan, mycotoxins, volatile organic compounds (VOCs), particles of plant origin and particles of animal or human origin.

- Viruses occur mainly in droplet aerosols generated by humans and animals during various life functions. The most hazardous are viruses causing respiratory diseases.

- Bacteria occur commonly in various agricultural dusts. It was found that their concentration in the air of various agricultural settings was high, ranging from $10^{3}-10^{6} \mathrm{CFU} / \mathrm{m}^{3}$, and showed a significant correlation with work-related symptoms in exposed persons $(\mathrm{P}=0.030)$ [12]. Many species of bacteria occurring in this environment were identified as a source of pathogenic glycoprotein allergens, and of macromolecular inflammatory immunotoxins located in the cell wall: endotoxin (LPS) produced by Gram-negative bacteria, peptidoglycan produced by Gram-negative and Gram-positive bacteria, and lipoteichoic acid (LTA) produced by Gram-positive bacteria [11-13]. The numbers of Gram-positive bacteria (mostly corynebacteria and staphylococci) are higher compared to Gram-negatives; however, the medical importance of the latter is greater because of strong allergens and potent endotoxins. The concentrations of bacteria in dwellings are low $\left(10^{\circ}-10^{2} \mathrm{CFU} / \mathrm{m}^{3}\right)$ and usually do not pose a health risk to the inhabitants [14].

- Bacterial endotoxin is the best known and most important macromolecular compound present in agricultural bioaerosols. Endotoxins are biologically-active lipopolysaccharides (LPS) that are integral components of the outer membrane of the cell walls of Gram-negative bacteria. Structurally, they are macromolecules, resulting from the polymerization of smaller LPS units with proteins and phospholipids of the cell wall. The authors have shown that the fragmentation of the cell wall easily releases them into airborne dust in the form of ultrafine microvesicles (Fig. 3) [15, 16]. They have also demonstrated that the concentration of endotoxins in the air of various agricultural settings was very high, ranging from 


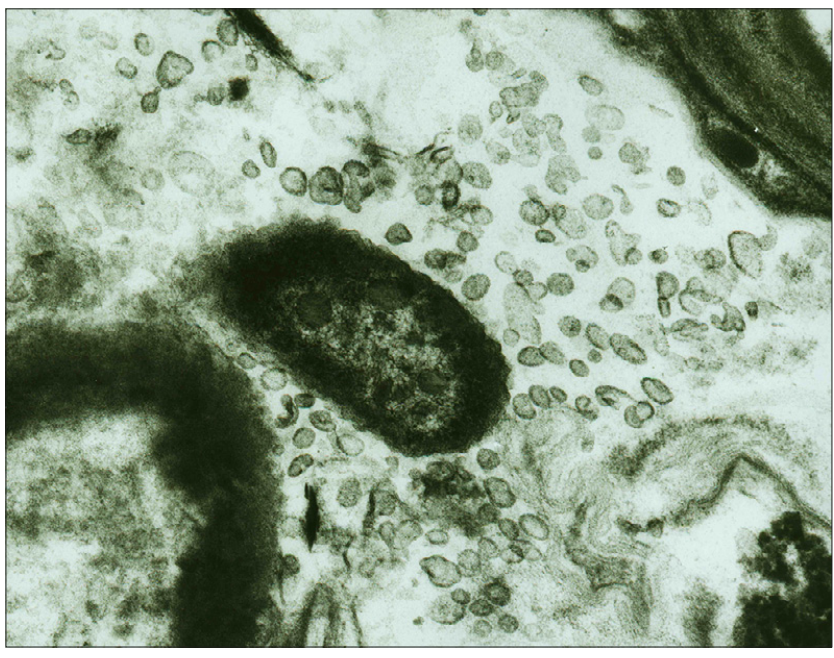

Figure 3. Transmission electron microscopic image of grain threshing dust. In the centre, cell of Gram-negative bacterium surrounded by numerous endotoxincontaining microvesicles (ECMV), released into dust by fragmentation of the bacterial cell wall, $\times 55,000$.

Source: Institute of Rural Health, Lublin [13]. Author: Dr Barbara Urbanowicz, Jagiellonian University, Kraków, Poland

100-106 $\mathrm{ng} / \mathrm{m}^{3}$, and showed, similar to the concentration of bacteria, a significant correlation with work-related symptoms in exposed persons $(\mathrm{P}=0.034)$ [12]. Endotoxins inhaled by humans together with dust binds via the TLR4 receptor to the surface of alveolar macrophages, causing non-specific activation of these cells which, in turn, release numerous substances (phospholipids, cytokines) known as inflammatory mediators. Symptoms resulting from inflammation of the airways include chest tightness, fever and gas exchange disorders [10, 12, 17].

- Fungi are less common than bacteria in the occupational aerosols. For example, the concentration of fungi in the air of agricultural settings determined by the authors ranged from $10^{3}-10^{4} \mathrm{CFU} / \mathrm{m}^{3}$, and did not show a significant correlation with work-related symptoms in exposed persons $(\mathrm{P}=0.063)$ [12]. Nevertheless, moulds present in various dusts, mostly those belonging to the genera Aspergillus, Penicillium, Cladosporium, Alternaria and Fusarium, pose an occupational hazard as a source of allergens, low-molecular toxic metabolites such as mycotoxins and volatile organic compounds (VOCs), and of high-molecular immunotoxic constituents of the cell membrane $((1 \rightarrow 3)-\beta$-d-glucan $)[11,18]$. It has long been believed that these pathogenic substances are located predominantly in fungal spores; however, Górny et al. [19] demonstrated that not only spores but also small fragments of hyphae possess potential allergenic and immunotoxic properties.

Mycotoxins are poisonous, non-volatile metabolites with a cyclic structure and low molecular mass (average 200 - 400 daltons). More than 100 types of mycotoxins have been classified, of which the most important are aflatoxins produced by Aspergillus flavus and trichothecenes produced by Fusarium spp. Mycotoxins present in the air of mouldy houses are suspected of exerting toxic and/or carcinogenic effects; however, their measured concentrations appeared to be low (between $10^{-1}-10^{2} \mathrm{ng} / \mathrm{m}^{3}$ ) and their pathogenic role needs to be confirmed. Volatile organic compounds (VOCs) produced by moulds include low molecular compounds (alcohols, aldehydes, ketones, organic acids, salts) that may exert irritative and toxic effects. $(1 \rightarrow 3)$ - $\beta$-d-glucans are polymers of $\mathrm{d}$-glucose molecules and are present in the cell wall of fungi. Inhaled with dust, they stimulate the reticuloendothelial system and activate alveolar macrophages which secrete mediators, initiating an inflammatory reaction in lung tissue. All these toxic compounds produced by moulds are implicated in the pathogenesis of condition occurred in mouldy homes and offices, and described as 'building-related disease' $[10,11,13,18,20]$.

Plant particles released to the air from crushed and pulverized plant materials processed for food (e.g. tea, coffee, castor bean), drugs (e.g. psyllium, ipecacuanha) or enzymes (e.g. papaya, pineapple), may be a cause of allergy in exposed workers. Some wood dusts may exhibit allergenic or carcinogenic properties. The flower pollens of grasses, weeds and trees are well-known aeroallergens that may cause allergic rhinitis (pollinosis), asthma and dermatitis in sensitive persons [10].

Animal particles include the allergenic particles of mites which are mostly enzymes occurring in faecal pellets. The mites belonging to the Acaridae family (such as Acarus siro, Tyrophagus putrescentiae) feeding on grain and other stored materials, evoke rhinoconjunctivitis, dermatitis and asthma in agricultural workers, while those belonging to the Pyroglyphidae family (Dermatophagoides pteronyssinus, Dermatophagoides farinae) occurring in dwellings, evoke the same disorders in home inhabitants [11].

The strong allergenic properties exhibit protein allergens of marine animals (shrimps, prawns, crabs, mussels, squids, fish) which are common causes of asthma in workers exposed to the inhalation of bioaerosols containing these allergens during the production of seafood [10, 21-24]. The major allergen responsible for allergy to 'shellfish' (crustaceans and mollusks) is tropomyosin, a two-stranded $\alpha$-helical coiledcoil protein found in cell cytoskeletons, although other allergens may play an important part in allergenicity, such as arginine kinase and the myosin light chain [22]. Jeebhay et al. [23] report that the concentration of the specific allergen in the air during the processing of various seafood ranged from $0.001-5.061 \mu \mathrm{g} / \mathrm{m}^{3}$, while Griffin et al. [24] found that the concentration of airborne scampi (shrimp) allergen during shelling process attained the level of $8.5 \mu \mathrm{g} / \mathrm{m}^{3}$. The prevalence of occupational asthma among seafood producers ranged from $7 \%-36 \%$, and of occupational protein contact dermatitis from $3 \%-11 \%$ [23].

Bird breeders and employees of poultry processing plants are exposed to the inhalation of dusts containing allergenic fragments of the feathers, epidermis, excrement and secretions of birds, which may lead to bird fancier's lung, a specific form of hypersensitivity pneumonitis (HP). About $10 \%$ of employees of plants producing egg powder were diagnosed with occupational asthma resulting from exposure to high concentrations $\left(2.0-50.0 \mu \mathrm{g} / \mathrm{m}^{3}\right)$ of protein allergen found in chicken eggs [20,25].

Mammal allergens are found in particles of epidermis, hair, and excrement, as well as droplets of saliva, milk, and urine released into the air. The most significant are protein allergens belonging to the group of lipocalins which are produced by laboratory rodents, and occur abundantly in the urine of rats and mice. They cause a syndrome consisted 
of asthma, rhinoconjunctivitis and urticaria, described as 'Laboratory Animal Allergy' (LAA). The concentration of the rat urine allergen in the air of vivaria may range from $0.0015-50.6 \mu \mathrm{g} / \mathrm{m}^{3}[20,25]$.

Farmers are often diagnosed with allergies to the substances found in the epidermis and hair of cows, and in pig urine. The concentration of the cow epidermis allergen in the air of cow barns ranges from $0.04-9.5 \mu \mathrm{g} / \mathrm{m}^{3}[20$, 25]. Occupational asthma has also been observed in workers exposed to the inhalation of powdered milk containing the allergenic $\alpha$-albumin [25].

\section{RESPIRATORY DISEASES CAUSED BY EXPOSURE TO OCCUPATIONAL BIOAEROSOLS WITH REGARD TO THEIR POSSIBLE INTERRELATIONS WITH THE COVID-19 PANDEMIC AS COMORBIDITIES}

Exposure to bioaerosols may evoke, depending on the kind and concentration of adverse factor(s), three types of diseases: infectious, allergic and immunotoxic.

Infectious diseases. Many species of viruses and bacteria present in droplet and dust bioaerosols may cause respiratory and/or systemic infectious disorders co-existing with COVID-19 and exacerbate the course of this disease. To this group belong numerous viruses spread by droplet aerosols of human origin presenting a primary occupational hazard for health care and social care workers, such as SARS viruses, influenza viruses, human respiratory syncytial virus (RSV), pneumovirus RS (RSV), rubella virus, mumps virus, varicella zoster virus (VZV), and rhinoviruses, causing the common cold [10]. Health care and social care workers may also be exposed to infectious bacteria spread by droplet aerosols, such as Klebsiella pneumoniae causing pneumonia, mostly in immunocompromised persons, Bordetella pertussis causing whooping cough, Mycobacterium tuberculosis causing tuberculosis of lungs, and methicillin-resistant Staphylococcus aureus (MRSA) strains causing systemic diseases $[10,11,20]$.

Farmers, workers in the meat and poultry industries, furriers and veterinarians may be exposed to the inhalation of dust- and (more rarely) droplet aerosols containing particles of animal origin (faeces, urine, secretions, epidermis, hair, feathers), together with various zoonotic viruses and bacteria causing pneumonia and/or systemic disease. Pathogens belonging to this group include: avian $\mathrm{A}(\mathrm{H} 5 \mathrm{~N} 1)$ and swine $\mathrm{A}(\mathrm{H} 1 \mathrm{~N} 1)$ influenza viruses; hantaviruses developing in rodents which may cause haemorrhagic fever with renal syndrome (HFRS); Chlamydia psittaci, a small bacterium found in many captive-bred and wild birds, causing ornithosis, a disease which takes the form of interstitial pneumonia, accompanied by high fever; Coxiella burnetii, another small Gram-negative bacterium occurring mostly in sheep, goats and cattle that cause Q-fever, a disease developing mostly as an influenza-like fever which may be accompanied by interstitial pneumonia; Bacillus anthracis, a spore-forming Gram-positive bacterium occurring also in ruminants that cause ulcers observed in the form of pulmonary, skin or intestinal disease, now detected mostly in developing countries; Francisella tularensis, a Gram-negative bacterium developing mostly in hares and rodents, causing tularemia, a disease that can take a pulmonary, glandular, or gastrointestinal form; Streptococcus suis, a Gram-positive bacterium occurring in pigs, causing meningitis, septicaemia, arthritis, endocarditis and deafness $[10,11,20]$.

A fastidious Gram-negative bacterium Legionella pneumophila, occurring commonly in water distribution systems, causes legionellosis, a severe respiratory disease appearing as atypical pneumonia, or a milder influenzalike illness named 'Pontiac fever'. These diseases may occur in people exposed occupationally to bacteria-laden water aerosols (such as plumbers, turbine operators, workers employed at cooling towers or sewage treatment plants) and in those exposed to such aerosols when bathing [10, 11].

On the basis of observations made during the present COVID-19 pandemic, Bengoechea and Bamford [26] expressed an opinion that secondary SARS-CoV-2 infection may exacerbate existing bacterial infection and, conversely, a secondary bacterial 'super-infection' may exacerbate the course of existing COVID-19. They postulate that each scenario of co-infection will worsen the clinical outcome and severity of COVID-19 by increased dissemination of both pathogens, suppression of host immune defense and increased tissue damage. The authors also indicate that the over-treatment of COVID-19 patients with antibiotics increases the prevalence of multidrug-resistant bacterial strains, and the risk of nosocomial infections in hospitalized patients.

Allergic diseases. Bronchial asthma and hypersensitivity pneumonitis (HP), often evoked by inhalation exposure to various bioaerosols, appear as the most important comorbidities which may influence the clinical course of COVID-19. The knowledge extant on this subject and the formulation of some hypotheses on possible interrelationships between these diseases is presented below.

Asthma. The disease occurs mostly in 'atopics', i.e. genetically predisposed individuals. It is caused by sensitisation to highmolecular-weight glycoprotein or protein allergens, mostly of microbial, plant and animal origin, that are often in the $20-50 \mathrm{kDa}$ range. The pathological reaction is mediated by lymphocytes Th2 that induce production of specific antibodies of Ig-E class which react with inhaled allergen on the surface of lung mastocytes and basophils. As a result of this reaction, lung cells release inflammation mediators (such as histamine, leukotrienes, prostaglandins) which cause bronchospasm with mucus secretion, described as 'asthmatic attack' $[10,27,28]$.

It is estimated that occupational asthma accounts for $2-15 \%$ of all asthma cases. It may be caused by various constituents of bioaerosols, often by enzymes obtained from bacteria, fungi, fruits and animal organs that are used in various industrial processes. The other common allergens causing asthma occur in moulds, yeast, mushrooms, dusts from cultivated or pulverized plants, wood dust, mites, insects, marine animals used for the production of seafood, and particles originating from birds and mammals [10,28].

In contrast to other allergic and immunotoxic diseases that may be due to bioaerosol exposure, the significance of asthma in relation to COVID-19 has been studied and discussed by many authors [29-40]. Nevertheless, the data interpretation and conclusion formulation are difficult because of the variable prevalence of asthma in the general population, which is usually much greater in the USA and 
Europe compared to China and other Asiatic countries [29]. The US Centers for Disease Control and Prevention (CDC) unequivocally classified patients with underlying moderate to severe asthma as a high-risk group susceptible to severe COVID-19 [30]. This view was supported by Abrams et al. [31] who expressed an opinion that individuals with asthma are over-represented among the adult patients who have been admitted to hospital with COVID-19 diagnosis. This is due to the fact that they explained that SARS-CoV-2 triggers asthma exacerbations similar to other viruses. Although both these views seem logical, they were questioned by a group of other authors, among whom Jackson et al. [32] demonstrated significantly reduced $A C E 2$ gene expression in the airway epithelium of asthmatic patients, which interferes with SARS-CoV-2 entry to host cells, and according to these authors, decreases the probability of severe COVID-19 in these patients. This view has been confirmed by LovinskyDesir et al. in New York [33] who found that asthma diagnosis was not associated with worse outcomes in patients with severe COVID-19, and by Chhiba et al. [34] in Chicago who stated that in COVID-19 patients, asthma was not associated with an increased risk of hospitalization, in spite of the fact that asthma prevalence in this group (14.4\%) was significantly greater compared with the general US and metropolitan Chicago population ranging from 8 9.5\%. A view on the under-representation of asthma among COVID-19 patients was shared by a group of other authors $[7,35,36]$ who mentioned three reasons for this: reduced expression of ACE2 and TMPRSS 2 enzymes in host cells, protective antiviral effects of cytokines and accumulation of eosinophils occurring in type 2 immune response occurring in asthma, and possible beneficial effects of drugs used for the treatment of asthma.

Nevertheless, more recent studies seem to revise the abovementioned views on the self-protection of asthma patients against COVID-19. Peters et al. [37] found that both ACE2 and TMPRSS2 genes expression levels in sputum cells of asthma patients and healthy subjects were similar, while the gene expression for ICAM-1 (intercellular adhesion molecule 1) was higher in asthmatics. Sajuthi et al. [38] and Radzikowska et al. [39] demonstrated a higher TMPRSS2 gene expression in human bronchial epithelial cells of asthma patients than healthy individuals. The latter authors concluded that the airway epithelium in asthma and COPD showed a gene signature that potentially can facilitate SARS-CoV-2 entry, and enhance internalization after receptor binding [39]. The results of these genetic studies were supported by an epidemiological study of Williamson et al. [40] conducted in England on a very large cohort of 17.3 million adult inhabitants. They demonstrated that the risk of COVID19-related death was significantly associated, among other factors, with severe asthma.

In conclusion, the results of the most recent studies seem to confirm the above-mentioned opinion of CDC [29] that asthma may exacerbate COVID-19. Conversely, COVID-19 may most probably aggravate existing asthma. Wark et al. [41] documented in their comprehensive review that viral infections are responsible for the majority of asthma exacerbations ( $80 \%$ in children and $76 \%$ in adults). Nevertheless, the view of Morais-Almeida et al. [29] on the need for further studies on the interrelationship asthmaCOVID-19, is certainly correct, in particular with respect to occupational asthma.
Hypersensitivity pneumonitis (HP). This is an allergic, interstitial lung disease, typically caused by occupational exposure to large amounts of microorganisms or animal particles containing glycoprotein or protein antigens. In contrast to asthma, the pathological reaction is mediated by lymphocytes Th1, to a lesser extent by immune complexes of precipitating antibodies with invading allergen. The reaction evokes granulomatous inflammation of the peripheral gas exchange lung tissue, associated with the expression of Th1 cytokines (including TNF- $\alpha$, IL-12, and IFN- $\gamma$ ), alveolar macrophage activation, and mononuclear cell recruitment. The continuous exposure to allergens leads to critical changes in the lung, culminating in fibrosis and permanent lung damage $[10,42,43]$. Compared to asthma, $\mathrm{HP}$ is a rare disease, for example the yearly incidence of this disease among Swedish farmers was 2 - 3/10,000 [44]. Nevertheless, it is generally regarded as being under-diagnosed [42].

HP comprises a number of subunits named after the occupations associated with exposure to the disease-evoking allergens, such as: farmer's lung associated with exposure to mouldy hay or grain; bird fancier's lung associated with exposure to avian antigens, or machine operator's lung associated with exposure to aerosol from metalworking fluids. More than 300 antigens have been identified todate as causative agents of the disease. They include a large variety of microorganisms of which the most important are: thermophilic actinomycetes of the species Saccharopolyspora rectivirgula and Thermoactinomyces vulgaris developing in overheated hay or grain, non-tuberculous mycobacteria belonging to Mycobacterium immunogenum, and the Mycobacterium avium complex developing in metalworking fluids, Gram-negative bacteria of the species Pantoea agglomerans developing in grain, wood and other plant materials, and many fungal species belonging to genera Aspergillus and Penicillium present in mouldy plant materials. HP may also be caused by antigens of bird origin, present in droppings, faeces, epithelium and feathers, as well as by protein antigens of other animals, and rarely by antigens of plant origin [10, 42, 43, 45-51].

There are strong indications that SARS-CoV-2 may initiate or exacerbate HP symptoms, similar to other pathogenic viruses. The role of respiratory viruses in the aggravation of the course of HP has been convincingly demonstrated by the team of Professor Yvon Cormier in Montreal, Canada [52-55]. Dakhama et al. [52] reported a high prevalence of influenza A virus and the presence of adenovirus, coronavirus subtype OC43, and parainfluenza type 3 virus in the lower airways of farmers with HP diagnosis, whereas the prevalence of influenza A virus in healthy controls was detected on a low scale. The number of total cells recovered in bronchoalveolar lavage (BAL) was significantly higher in patients with influenza A virus, indicating an enhanced inflammatory process. These clinical observations suggesting a probable role of viruses in the modulation of HP are in accordance with the earlier experiments performed in mice by Cormier et al. $[53,54]$. They showed that the infection with murine respirovirus (Sendai virus) enhances the cellular response of the mouse lungs to antigenic challenge with Saccharopolyspora rectivirgula, a known agent causing HP [53]. Cormier et al. [54] demonstrated that mice subjected to repeated challenges with $S$. rectivirgula, followed by a single infection with parainfluenza virus, developed an exacerbated inflammatory response shown by significantly 
increased BAL levels of TNF- $\alpha$ and IL-1 $\alpha$, as well as increase of the proportion of large foamy macrophages. Cormier and Israël-Assayag [55] expressed an opinion that respiratory viruses may trigger HP symptoms in individuals exposed to causative antigens, as well as modulate the course of the disease by the increase of antigen-presenting capacity of alveolar macrophages, the release of pro-inflammatory cytokines, and proliferation of Th1 cells associated with HP development. The results obtained by the Cormier group were confirmed by Gudmundsson et al. [56] who demonstrated that mice infected with the respiratory syncytial virus (RSV) showed an augmented response to $S$. rectivirgula challenges, manifested both by the early increase in the neutrophil number and the amount of the macrophage inflammatory cytokine MIP-2 (equivalent to human IL-8) in BAL, as well as by the late increase in the amount of IL-2 cytokine in BAL and significantly more severe granulomatous inflammatory response, as assessed histologically. The authors mention that many patients who developed HP report a recent viral respiratory infection. This finding is in accordance with the observations of the authors of the current study, that during past 50 years a considerable number of farmers diagnosed with HP who were treated in the Clinic of Pneumonology of the Medical University in Lublin, eastern Poland, reported viral pneumonia as an onset of the HP disease [57].

Results of recent studies by the authors [58], as well as revision by Ochsner and McKenna [59], indicated epithelialmesenchymal transition (EMT) as a common molecular mechanism associated with HP and SARS-CoV-2 infection. EMT is a process by which fully-differentiated epithelial cells undergo a phenotypic conversion and assume a mesenchymal cell phenotype, including elongated morphology, enhanced migratory and invasiveness capacity, and greatly increased production of extracellular matrix components. The authors of this study have demonstrated for the first time that the saline extract of Pantoea agglomerans (one of the common etiological factors of hypersensitivity pneumonitis) induces EMT in the human lung epithelial cell line and murine lung tissue. Performed in vivo studies revealed a significant downregulation of gene expression for epithelial cells markers (E-cadherin, claudin 1, plakoglobin, occludin), accompanied by up-regulation of gene expression for mesenchymal cells markers ( $\alpha$-smooth muscle actin, $\mathrm{N}$-cadherin, fibronectin, vimentin), as well as induction of histological changes characteristic for pulmonary fibrosis in the course of HP [58].

Additional studies by the authors confirm that indicated changes in gene expression were reflected in the level of protein products of the mentioned genes. Furthermore, it was also discovered that chronic exposure of mice to $P$. agglomerans significantly increased expression of other genes and proteins involved in EMT, including transcription factors Nfkb1/NFkB, Snail1/Snail, Zeb1/ZEB1, Zeb2/ZEB2 [data not published]. Ochsner's and McKenna's large-scale data analyzes of the transcriptional response to coronaviruses (MERS-CoV, SARS-CoV-1, SARS-CoV-2) revealed that SARS-CoV-2 infection of airway epithelial cells is specifically associated with EMT. Among EMT-related genes affected by coronaviruses infection, the SARS-COV-2 high confidence targets were SNAI2, SOX2, GATA6, CTBP1 and PRMT1 [59].

Next to metanalysis data, studies conducted by Stewart et al. [60] have shown that SARS-CoV-2 induces changes in infected lung cancer cells consistent with EMT, including upregulation of $Z E B 1$, causing down-regulation of viral receptor
ACE2. Based on this data, they suggested a very interesting mechanism for the molecular virus-host interaction. They predict that SARS-CoV-2-induced ACE2 deficiency (mediated by transcription factor ZEB1) decreases the expression of epithelial markers, including claudins, which play a critical role in restricting epithelial permeability. Induced changes increase the risk of oedema and ARDS (acute respiratory distress syndrome) [60]. EMT involvement discovered in the pathogenesis of both COVID-19 and HP provides evidence for the possible coexistence of both diseases and of mutual interactions.

To-date, during the present coronavirus pandemic, HP comorbidity occurring with COVID-19 has not been analysed. Nevertheless, a striking similarity of the clinical symptoms occurring in severe COVID-19 to those appearing in the severe form of HP was noticed by Song and Shin [61], and later described in detail by Sanchez-Gonzalez et al. [51]. The latter authors demonstrated that in both cases, cytokine storm, macrophage activation, thrombosis, fibrosis and ARDS could be observed, often with a fatal outcome [51]. On the basis of the demonstrated similarity between severe COVID-19 and severe form of HP, SanchezGonzalez et al. [51] proposed that the novel SARS-CoV-2 can act simultaneously as a trigger and substrate of an HP-like severe immune reaction, especially in genetically-vulnerable individuals, in addition to those with immune senescence and dysregulation. This very sound proposal is discussed by the authors in the second part of their study devoted to clinical practice. Below, they attempt to anticipate the course of events that may follow the co-existence of both diseases elicited by different factors (SARS-CoV-2 vs. various antigens) in the same individual.

Four possible scenarios are proposed for the co-existence of COVID-19 and HP in one patient:

1) Two-hit triggering of severe HP by the infection with SARS$\mathrm{CoV}-2$ virus in the person exposed to antigens causing $\mathrm{HP}$ but not exhibiting disease symptoms, according to the 'two-hit' hypothesis, in which the environmental factor, i.e. the virus (the first hit) increases the risk for the development of severe HP after antigen exposure (the second hit) [51]. As a result, such a person develops a severe, mixed disease of COVID-19 co-existing with HP in which the pathological processes common for both clinical entities (such as hyperinflammation, cytokine overproduction, thrombosis, fibrosis and ARDS) may sum up or even act synergistically.

2) The reverse two-hit triggering of severe COVID-19 when exposure to antigen(s) causing HP (the first hit) exacerbates a symptomless or mild course of COVID-19 in the person infected with SARS-CoV-2 virus (the second hit), and evokes a severe COVID-19 disease. As a result, the patient develops a severe, mixed disease of COVID-19 co-existing with HP in which the pathological processes common for both clinical entities may sum up, or even act synergistically, as mentioned above.

3) Mutual exacerbation of mixed disease when an individual with severe HP develops severe COVID-19 (a reverse situation is rather not probable), resulting in a more severe disease, as mentioned above.

4) Co-existing of severe or symptomless/mild COVID-19 with a severe or symptomless/mild HP without exacerbation. This scenario has a low probability to exist in a real life. 
Immunotoxic diseases. These are diseases caused by airborne microorganisms or their products that dysregulate the human immune system by its excessive stimulation, depression or another impairment of its function. They are usually associated with organic dusts occurring in the occupational environment and mainly represent a risk for agricultural workers and for persons working or living in mouldy offices or dwellings. The most important diseases in this category are: Organic Dust Toxic Syndrome (ODTS, toxic pneumonitis, inhalation fever, grain fever), byssinosis, mycotoxicoses, and building-related disease. According to the best of the knowledge of the authors of the current study, no reports presenting the possible interrelationships between these diseases and COVID-19 have been published recently.

Organic Dust Toxic Syndrome (ODTS). The disease occurs usually in agricultural workers exposed to the inhalation of large quantities of organic dusts and associated bacteria and fungi, for example, at shuffling grain. ODTS occurs relatively often, for example, Malmberg et al. [44] found its yearly incidence among Swedish farmers to be 1/100, 30 - 50 times higher than that of HP. The disease is evoked mostly by macromolecular, microbial biopolymers mentioned above: bacterial endotoxin (LPS), bacterial peptidoglycan, and fungal $(1 \rightarrow 3)-\beta$-d-glucan. The flu-like symptoms of the ODTS largely resemble those occurring in acute HP; however, in contrast to HP, the disease appears without prior sensitization, does not cause spirometric, radiological and serologic changes, and occurs mainly in young people below 30 years of age $[10,44,62]$.

Bacterial endotoxin is regarded as the most important factor causing ODTS, mainly in the cases of massive exposure to grain dust. It is produced by Gram-negative bacteria, mostly those belonging to the species Pantoea agglomerans which prevails in microbiota of grain and other plant materials [49].

The study by Petruk et al. [63] is very important for understanding the possible interactions between endotoxin and SARS-CoV-2. They demonstrated that the SARS-CoV-2 spike protein binds to Escherichia coli LPS, leading to the boosting of pro-inflammatory actions in vitro by induction of NF- $\kappa \mathrm{B}$ (nuclear factor-kappa B) and cytokine responses in monocytes and human blood, as well as in vivo, by increased $\mathrm{NF}-\kappa \mathrm{B}$ responses in an experimental mouse model. This finding is relevant for studies on comorbidities of COVID-19 involving bacterial endotoxin, such as metabolic syndrome or, as in the current case, diseases evoked by exposure to endotoxin-containing bioaerosols. The study is in line with others indicating the role of LPS in the enhancement of the pathological effects caused by respiratory viruses, such as influenza A virus [64].

The risk of evoking a pulmonary disease by endotoxin and exacerbation of COVID-19 disease is enhanced by the fact that it occurs in organic dusts in the form of ultrafine particles. As mentioned above, between 1992 2000 , the authors of the presented study demonstrated by immunoelectron microscopy the presence of endotoxincontaining microvesicles (ECMV), measuring mostly 30$50 \mathrm{~nm}$, in the samples of wood dust and grain dust from the human working environment (Fig. 3) $[15,16]$. These ECMV particles, produced mainly by $P$. agglomerans and consisting of LPS, proteins and phospholipids, were released into dust by fragmentation of the cell wall. The authors separated them from the bacterial mass by differential sucrose gradients, and documented by a long-term inhalation experiment in rabbits the high pro-inflammatory activity of ECMVs, evidenced by the significant increase of cytokines (total IFN, IL-1a, TNF-a) in blood plasma, and the induction of specific immunity, both cellular and humoral [65]. It is noteworthy that ECMVs present in organic dusts are of a nanometric size similar to SARS-CoV-2 particles, which may facilitate an interaction between these two kinds of particles and stimulation of the virus by ECMVs. Of course, this presumption requires experimental confirmation.

The results obtained in the current study are in accordance with those of Mueller et al. [66] who evidenced that endotoxin aggregates (macromolecules) showed much higher biological activity than monomers. More recently, Yang et al. $[67,68]$ and Kim et al. [69] highlighted the significance of extracellular bacterial vesicles (EV), mostly those containing LPS, as potential causative factors of pulmonary inflammation, thus confirming the views published about 20 years earlier by the authors of the presented study. Yang et al. [68] expressed an opinion that EVs, especially Gram-negative outer membrane vesicles (OMVs), induce Th17 immune response and lead to neutrophilic inflammation which may contribute to the development of asthma, emphysema, COPD, and lung cancer. Summarizing, the exposure of patient with COVID-19 to the inhalation of organic dusts containing ECMVs may significantly increase the risk of exacerbation of the disease.

The possible scenarios for interrelations between COVID-19 and ODTS (no specific forms of this disease, such as 'mild' or 'severe' have been proposed until recently) are similar to those proposed above for HP and comprise:

1) 'Triggering - when infection with SARS-CoV-2 virus triggers ODTS in the person exposed to inhalable endotoxin or other factors causing ODTS, but not exhibiting disease symptoms.

2) 'Reverse triggering' - when exposure to factors causing ODTS exacerbates symptomless or a mild course of COVID-19 in the person infected with SARS-CoV-2 virus, and evokes a severe COVID-19 disease.

3) Mutual exacerbation of mixed disease - when an individual with ODTS develops severe COVID-19 (a reverse situation is rather improbable), resulting in a more severe disease, as mentioned above.

4) Co-existence of severe or symptomless/mild COVID-19 with ODTS without exacerbation (with a low chance).

Byssinosis and related diseases. This is an occupational lung disease caused by the inhalation of cotton, flax and hemp fibres. The clinical course of the acute stage, caused by exposure to bacterial endotoxin [70, 71], resembles ODTS, while the chronic stage, caused by long-term exposure to not yet fully identified microbial and fibre factors (such as fungal glucans, cotton tannin), resembles chronic HP [72]. The disease represents a serious occupational health problem in developing countries, among others in India, where about 20 million workers are employed in the textile industry [72]. The recent press note from that country by Gangan [73] reported high morbidity and mortality rates for COVID-19 in the workers of the textile industry settings located in the cities of Solapur, Malegaon and Bhiwandi in the Maharashtra State, and indicated byssinosis as comorbidity that contributes to severe course of COVID-19 and numerous fatalities. A similar relationship between occupational exposure to tobacco dust 
and increased morbidity and mortality rates for COVID-19 was reported for 'beedi workers', i.e. people employed at the production of Indian cigarettes called 'beedi', made by wrapping shredded tobacco in the leaves of Diospyros melanoxylon or Bauhinia racemosa trees [73].

The possible scenarios for interrelations between COVID-19 and byssinosis are similar to those proposed above for HP and ODTS, and comprise 'Triggering', 'Reverse triggering', mutual exacerbation at mixed disease, and no effects at mixed disease.

Mycotoxicoses. These are diseases evoked by mycotoxins, low-molecular-weight secondary metabolites of moulds, mostly from the genera Aspergillus, Penicillium, Fusarium and Stachybotrys. The best known are their adverse effects after consumption of contaminated foods that may be carcinogenic, teratogemic, mutagenic or immunosuppressive. Their presence in the air is rather low; however, it could be high in bioaerosols released from some kinds of foods, such as groundnuts, which are a good substrate for toxin-producing fungi. Occupational exposure to such bioaerosols may result in the impairment of innate immunity and malignancies [74] which increases susceptibility to other disease agents, including COVID-19.

Building-Related Disease (BRD). This is a complex disease multi-factorial in its etiology and multifaceted in clinical course, with respiratory (dyspnoea, cough, wheezing) and/ or general symptoms (fatigue, headache, nausea) usually ascribed to microbial factors. A similar disease, the 'Sick Building Syndrome' (SBS), is usually caused by chemical, physical and psychological factors, such as gases, fumes or smoke. Symptoms of the BRD may be noted both in people living in 'ill' houses, as well as in those working in 'ill' buildings, mostly offices. Usually such 'ill' buildings show signs of damp and mould [75], and factors of fungal origin, such as $(1 \rightarrow 3)-\beta$-d-glucans, volatile organic compounds (VOCs) or mycotoxins, are usually considered as causative agents of the disorders in exposed people. In some cases, bacteria developing in a humid environment and their products should also be included in the list of suspected factors inducing disease symptoms $[10,18,75,76]$.

The COVID-19 pandemic forced many people to stay at home in order to cut the SARS-CoV-2 transmission chain from person to person, either because of quarantine prescribed by sanitary authorities after contact with an infected person, or coming from endangered places, or because of own free will in order to protect themselves and others. If an individual in quarantine lives in a damp or mouldy dwelling under risk of BRD or SBS and had been infected with SARS-CoV-2, his/ her stay at home can increase the risk of the severe form of COVID-19. Hosseini et al. [77] discuss other aspects of such a situation and express the sound opinion that a necessary, long-term stay at home forced by the pandemic may lead to an increase of indoor air pollution because of more activity, increased cooking and smoking, and overuse of disinfectants, which in turn leads to increased chemical pollution. All these factors, plus enhanced stress, may lead to BRD/SBS and an elevated risk of severe COVID-19 in the case of infection.

\section{OCCUPATIONS AT RISK OF COVID-19 AND ASSOCIATED COMORBIDITIES}

The recognition of occupational groups threatened by COVID-19 is usually performed according to two criteria:

1) Contacts with large numbers of individuals among whom, potentially, there could be persons infected with SARS$\mathrm{CoV}-2$. The examples of such groups are: health care workers, social workers, transportation workers, teachers, policemen, and workers of such industrial settings where close contact of workers is necessary for the production process.

2) Exposure to environmental factors, mostly bioaerosols containing particles of SARS-CoV-2 or other biological particles that may activate the pathogenic virus. The groups fulfilling this criterion are reviewed below.

Health care workers (HCWs). This occupational group, in the frontline of combating COVID-19, is widely recognized as the most endangered profession [5, 9, 78, 79]. This view is documented by medical statistics. For example, in Poland between 4 March - 2 November 2020, as many as 395,480 infections with SARS-CoV-2 and 5,875 fatalities were officially reported. Of this number, 25,743 HCWs were infected ( $6.5 \%$ of total infections), of whom 1,718 were hospitalized (6.7\% of infected HCWs) and 36 died $(0.6 \%$ of total fatalities) [80]. The fact that HCWs accounted for $6.5 \%$ of the total infected Polish population confirms the high occupational risk of this group, and is in line with an earlier publication [5] reporting that HCWs formed $48 \%$ among the non-hospitalized persons with a mild form of COVID-19 of occupational origin. Despite the presented statistics, the undoubted positive findings are: a relatively low percent of severe cases and a very low mortality rate which indicate a high consciousness of risk among HCWs and the proper use of prevention measures [80].

In the countries where much higher morbidity and mortality rates occurred, compared to Poland, such as Italy and Spain, the numbers of COVID-19 cases among HCWs were also high, accounting for $10 \%$ and $20 \%$ of the total cases reported until 23 April 2020, respectively. In Italy, until this date, the total number of 17,000 HCWs with COVID-19 were registered [5]. In China, among the first 138 patients treated in a Wuhan hospital, 40 patients (29\% of all cases) were HCWs. In the whole of China, until 11 February 2020 , 1,716 HCWs had been infected, among whom six died, with a mortality rate $(0.35 \%)$ even lower than in Poland [78].

When discussing a possible virus spread in the working environment of HCWs, as well as in other working environments, the importance of recent publications must be highlighted which clearly demonstrate that the airborne transmission of SARS-CoV-2 via small airborne microdroplets (commonly referred to as 'aerosols') is the most important route of human infection [3, 81]. Zhang et al. [3] showed that airborne transmission, particularly via nascent aerosols from human atomization, is highly virulent and represents the dominant route for the transmission of COVID-19. Morawska et al. [81] in their review article cited the results of air sampling in the patients' hospital rooms in Singapore and the USA, where the presence of SARS-CoV-2 was detected, ranging from 1.8 - 4.1 viral RNA copies per one litre of air. They reported that the half-life of the SARS$\mathrm{CoV}-2$ virus in airborne particles is more than one hour, so it can potentially be inhaled by susceptible individuals 
causing infection and further spreading of the disease. Finally, the authors stated that airborne transmission is the main route of the virus spreading, and indicated enhanced air exchange as a key element in limiting the spread of the SARS-CoV-2 virus [81]. Altogether, the recent articles show that this virus may spread by the airborne route for much greater distances than the recommended two metre social distance. This fact significantly increases the infection risk in working environments.

Social workers (in particular age care facilities workers). Although this occupational group should be classified only according to the first criterion (close contacts), the real life facts show that the workers of age care facilities are under a very high risk of infection which often occurs among elderly persons [79]. As such people are vulnerable to the severe form of COVID-19, the infection of one person may result in an outbreak of the disease spreading among the occupants of the facilities, and also among social care workers as a result of airborne virus transmission.

Laboratory workers employed at scientific and public health laboratories are at risk of infection when isolating viruses from environmental or clinical samples, working with the SARS-CoV-2 tissue cultures, performing experiments on laboratory animals with the use of SARS-CoV-2, or performing similar tasks.

Workers in the biotechnology sector are at the risk of infection when manufacturing various preparations from SARS-CoV-2, such as vaccines or diagnostic tests.

Workers of sewage treatment plants are at the risk of infection, as the SARS-Cov-2 virus has been detected in sewage and wastewater [2].

Workers in the textile industry. The workers of factories processing plant material (cotton, hemp, flax) are at the risk of the exposure to bioaerosols causing byssinosis, which is greatest in developing countries. As mentioned above, it has been recently shown in India that byssinosis as a comorbidity of COVID-19 increases the risk of the severe form of the disease and death [73].

Workers of the tobacco industry. Similar to workers of the cotton industry, tobacco processing workers are exposed to bioaerosols of plant origin containing microorganisms and their products which may cause allergic and/or immunotoxic diseases. It has been shown recently in India that these diseases as comorbidities of COVID-19 increase the risk of the severe form of the disease and death in this occupational group [73].

Farm workers and workers in the agricultural industry. From a global perspective, this is a large population under increased risk of severe COVID-19 resulting from possible comorbitidies, such as the above-mentioned HP or ODTS, caused by the work-related exposure to bioaerosols. Finding this causal relationship may be impeded by the fact that work-related diseases are often under-diagnosed, or appear in the initial, subclinical form without symptoms but with significant dysregulation of the immune system, facilitating the development of severe COVID-19.
The increased risk of farm workers for developing COVID-19 has been recognized for the first time in the USA $[82,83]$. According to National Center for Farmworker Health, Inc. (NCFH) report [82], as many as 880,000 rural residents tested positive for COVID-19, among whom 19,643 died. The substantial growth of the COVID-19 case rate was noted in rural areas. It increased during 90 days (beginning in May 2020) by 392\%, from 28.95 to 191.2 per 10,000 residents. The authors of the report regarded rural Americans as more vulnerable to COVID-19 than urban ones, and as risk factors were mentioned: a higher proportion of elderly persons, higher smoking usage, higher prevalence of certain chronic disease, and a lower proportion of persons covered by health insurance. Presumably, chronic respiratory diseases which may be due to bioaerosols are among 'certain chronic diseases'. The authors quoted a long list of COVID-19 outbreaks on farms in 17 states, including farms producing vegetables, fruit and mushrooms, as well as hog and poultry meat. Tuirán and Roberts [83] quoted the results of the research by Dr. Don Villarejo, who found that as of 1 July 2020, the prevalence of COVID-19 among agricultural workers in Monterey, California, was 1,410 positive cases out of 100,000, which was three-fold more compared to the rate for workers in all other industries. In another study, Dr Fielding-Miller found that across the country, the death rate from COVID-19 was much higher in counties with a large population of farm workers. The risk factors were poor living and working conditions, with overcrowding, mostly among migrant workers [83], although exposure to bioaerosols cannot be excluded. To-date, this factor is much less known among researchers

So far, there are only a few data on the prevalence of COVID-19 among farm workers and workers of the agricultural industry in other countries worldwide. The study carried out at the beginning of the pandemic (16 January - 2 March 2020), in Hengyang, Hunan province, China, revealed a total of 48 confirmed cases of COVID-19; of these, 30 individuals (62.4\%) were engaged in agriculture (15 farmers +15 rural migrant workers) [84]. This suggests a rather large proportion of agricultural workers among the COVID-19 patients in China, however, no relevant conclusion can be drawn in the absence of details about the employment structure in Hunan province,

Taken together, some reports from the USA indicate agricultural workers as a high-risk group, nevertheless, much more data from other countries are needed to clearly and reliably trace this phenomenon. It is supposed that the problem of agricultural workers as a group threatened by COVID-19 could be particularly important in the developing countries. While in many countries of Europe, North America, and Australia there prevail large and well-equipped farms protecting the workers from close interpersonal contacts and high exposure to bioaerosols, the agrarian structure in many developing countries of Africa, Asia, and South America, usually does not assure any such comfort. As a result, millions of agricultural workers from developing countries are at high risk of exposure to hazardous bioaerosols, either containing the disease agent (SARS-CoV-2), or other biological agents that may activate the deadly virus. Thus, in the case of a long-lasting pandemic, financial and logistic support for developing countries for the respiratory protection of workers, mostly those exposed to high concentrations of organic dusts, would be urgently 
needed from the international organizations, such as the World Health Organization (WHO) and the International Labour Organization (ILO).

Breeders of fur animals. This occupational group has been distinguished from other agricultural workers because of the extremely high risk of infection with SARS-CoV-2, due to the fact that some species of fur animals, such as mink, are competent hosts of this virus. The high risk of contracting COVID-19 from minks (Neovison vison) was evidenced in April and May 2020 in The Netherlands which had the fourth-largest mink farming industry in the world. The disease in minks, which appeared as interstitial pneumonia, was detected in April at first on two farms and then spread to a further 17 farms. The animals were probably infected by farm workers who had COVID-19. In turn, in May, at least two farm workers caught the virus from mink and are the only patients anywhere known to have become infected by animals. Studies have shown that inhalable dust on farms contained viral RNA, clearly indicating a possibility of the airborne transmission of SARS-CoV-2 to workers of animal farms. As a result of this data, the Dutch parliament decided to put an end to the nation's mink farming industry and to cull 600,000 animals [85-87]. Recently, COVID-19 occurred on 61 mink farms in Denmark, the world's largest producer of mink pelts. Consequently, the Danish government also decided to cull around one million minks [88].

Taking together, the above-presented facts show a considerable risk of COVID-19 in breeders of fur animals that may be aggravated by allergy to animals' hair. These facts provide an additional, important argument for the humanitarian termination of such breeding in all countries engaged in fur animal breeding, including Poland.

Workers of meat and poultry processing facilities. It has been proven that the risk of COVID-19 is enhanced in these occupational groups $[79,89,90]$. According to the CDC data collected during 9 - 27 April 2020, COVID-19 cases were detected among 115 meat or poultry processing facilities in 19 States of the USA. The disease was diagnosed in 4,913 workers (approximately $3 \%$ of the total staff), and 20 COVID-19-related deaths were reported [89]. As of 25 June 2020 , as many as 25,000 meat and poultry workers in the USA were reported to have COVID-19, among whom at least 93 died [91]. As of 1 October 2020, COVID-19 outbreaks were noted already in over 700 meat packing and food processing plants, which caused an increased risk of infection among workers and caused a decline in US beef and pork production by $40 \%[82]$.

The reports from the USA on the increased risk of COVID-19 among workers of slaughterhouses and meatpacking plants were confirmed in other parts of the world. In Germany, a huge COVID-19 outbreak in Gütersloh, North Rhine-Westphalia, was noted. More than 1,500 of 7,000 workers of the big slaughterhouse (above 21\%) tested positive for COVID-19. At one of Portugal's biggest poultry slaughterhouses, at least 129 of the 300 workers (43\%) contracted the disease. In England and Wales, outbreaks associated with meat were recorded in four meat processing facilitie, with 469 workers infected [ 90 , 91]. In Australia, a COVID-19 cluster was reported among slaughterhouse workers in Melbourne [79].

The overcrowded working places, associated with the conveyor belt production system, do not allow for keeping a safe distance between workers and are regarded as a risk factor of the disease. The other risk factors, favouring the persistence of the virus, are low temperature and high humidity, dense production of bioaerosols combining dust, feathers, and faeces, as well as the presence of metallic surfaces $[89,90]$. The important risk factor is the above-presented possibility of airborne virus transmission $[3,81]$ which may be increased by air filtration systems [90]. The severity of the disease could be enhanced by allergic comorbidities associated with exposure to bioaerosols, such as HP caused by sensitivity to poultry particles, or asthma caused by allergy to cow or hog particles [25].

Workers engaged in processing and selling of seafood. This is the first occupational group ever identified as having been at risk of COVID-19 [78]. The world's first group of patients with the diagnosis of the disease later named COVID-19 derived from Wuhan, a big city in Hubei province, eastern China. The majority of this group (27 out of $41-66 \%$ ) were linked to the Huanan Seafood Wholesale Market having contact with marine animals: crustaceans, mollusks and fish [4]. The first four COVID-19 patients came from Huanan Market, including 'patient zero' - a woman selling shrimps [92]. Most of the 41-person group (76.4\%) had severe pneumonia with mortality in this group at $15 \%$ [4].

The source of the infection that began a world-devastating pandemic has not been identified. According to the best knowledge of the authors of the current study, the exact data concerning the Huanan Market that could help scientists from other countries to resolve the enigma (such as the list of all marine animal species traded, their numbers, procedures of seafood processing used in the Market, results of air sampling (if any), and allergological testing of vendors (if any), have not been published. Therefore, researchers have had to rely solely on the press notes (if any). By now, it may only be presumed that some of the vendors working on the market responded to allergic or immunotoxic bioaerosols released during the processing of marine life, such as shrimps and/or fish known to produce strong allergens and/or immunotoxins (as mentioned above), and developed allergic (asthma, HP) or immunotoxic (ODTS), diseases which later facilitated development of the viral disease. Knowledge of the procedures applied during the processing of seafood in the market would be vital for solving this problem as such procedures may bring about unexpected results. For example, Bertelsen et al. [93] demonstrated that the workers of a savoury seafood factory experienced ODTS symptoms when producing shrimp shell powder. The study showed that the symptoms were due to a high content of bacterial endotoxin in the shrimp shells; thus, it was not a shrimp protein allergen that could have been expected, but a microbial factor that proved to be the disease-eliciting factor. There are some hints indicating a possible involvement of shrimps in the pathogenic process: the 'patient zero' in Wuhan was a shrimp seller [92], and the outbreak of COVID-19 in Ecuador occurred in Guayaquil [94], a shrimp production centre. It needs to be highlighted that a possible activation of the virus by shrimp allergens may follow only by the inhalation route, while the consumption of shrimps is quite safe and recommended as a source of nourishing protein.

It is noteworthy that the initial outbreak of COVID-19 in December 2019 has been followed recently by two similar outbreaks, both among people linked to seafood markets 
located in big cities in eastern China. The first occurred in Beijing's Xinfadi market in June 2020 and the second in the Dalian market in July $2020[95,96]$. Dr. Wu Zunyou, the chief epidemiologist of the Chinese Centre for Disease Control and Prevention, indicated in an interview that all the outbreaks in three cities, Wuhan, Beijing and Dalian, related to both seafood processing or sales on the markets. Dr. Zunyou stated that all these markets have a common environment that is humid and have a relatively low temperature which are suitable for the virus to survive, and indicated the risk of airborne transmission on the markets [96]. This is very important and useful information, but one question still remains unanswered: what was the source of all three outbreaks?

In conclusion, workers engaged in both seafood processing and selling are exposed to the inhalation of the protein allergens of marine life (shrimps, prawns, crabs, mussels, squid and fish), and probably also to some microbial factors such as endotoxin. These agents, causing allergic and/or immunotoxic diseases, may activate SARS-CoV-2 in an as yet unknown way, contributing to the common occurrence of COVID-19 in this occupational group.

\section{TRYING TO UNRAVEL THE ‘MYSTERY OF THE HUANAN MARKET'}

At the beginning of 2020, a deadly virus emerged in a seafood market in China which within a short time caused devastation worldwide. Even now the source of this virus remains unknown which hampers efficient combating of the disease. Various animal species were suspected as possible sources of the disease, however, none has been identified as such. Bats are probably reservoir hosts for SARS-CoV-2, but rather not intermediate hosts which could have transmitted the virus to humans in Huanan Market $[1,2]$. None of the other suspected hosts, including pangolins and snakes, were confirmed as a source of disease. In this situation, the authors of this study suggest forward two hypotheses as possible solutions to the 'Mystery of Huanan Market'.

1) The first hypothesis assumes that there was no intermediate host. A mild form of the present SARS-CoV-2, causing no symptoms, circulated and still circulates in the Chinese population inhabiting the eastern part of the country. Affected by as yet unknown factor(s) present in the Chinese seafood markets, probably component(s) of bioaerosols (such as tropomyosin and/or bacterial endotoxin), the virus mutated into the virulent and highly contagious form known as the present SARS-CoV-2, exactly according to a scenario similar to that named previously by the authors as 'Reverse triggering', with the difference that the external factor was not an 'activator' but a 'mutagen'. As a cause of the mutation, a possible genetic recombination cannot be excluded by the exchange of genetic material between the mild ancestor of the present SARS-CoV-2 and any of RNA viruses indigenous for animals sold on the market. The mutation can be recurrent because the initial outbreak at the Huanan Market in Wuhan was followed by two similar outbreaks at seafood markets in Beijing and Dalian. Most probably the mutant evokes the disease only in people not harbouring the pre-existing mild form of the present SARS-CoV-2, but not in its carriers, which contributes to the formation of herd immunity. This might explain, at least in part, a successful overcoming of the Beijing and Dalian outbreaks and of the whole COVID-19 epidemic in China. This hypothesis is in line with the work by Nishiura et al. [97] who, on the basis of the epidemiological reanalysis of the initial cluster of cases associated with Wuhan outbreak, presumed that the epidemic originated from the human-to-human transmission events within the market, rather than from animal-to-human transmission.

2) A much less probable hypothesis assumes the transmission of the mutated virus from any of invertebrate marine animals present on the market or from fish. Such interspecies transmission is a probable possibility because, for example, fish harbour bafiniviruses which belong to family Coronaviridae, while shrimps harbour roniviruses, classified together with coronaviruses in the same order, Nidovirales, and share some features with them [98, 99].

At present, these hypotheses cannot be proved. Nevertheless, it is believed that in the situation where COVID-19 is having a devastating effect worldwide, seeking an answer to the fundamental question about the origin of the disease is better than doing nothing essential. In this respect, the success of the Chinese scientists in the prompt identification of the pathogen and effective combating of the disease in their country is greatly appreciated. Nevertheless, the global community should not leave them alone in their efforts to resolve the mysterious origin of COVID-19. Therefore, the authors advocate support for the Chinese scientists by increasing the funding from the WHO, and sending an international team of scientists to China to assist in unraveling the question of the SARS-CoV-2 origin in situ. Identification of the origin of COVID-19 would help to stop the devastating pandemic, because of many reasons, for example, not least because isolation of the pre-mutated strain of the present SARS-CoV-2 would support the development of an effective vaccine.

\section{CONCLUSIONS}

1) Bioaerosols released during the handling of plant and animal materials in various facilities, or those occurring in animal breeding room, should be recognized as risk factors for COVID-19, and regarded as a potential cause of occupational comorbidities that may exacerbate the course of the disease.

2) The most important comorbidities caused by bioaerosols which may interrelate with COVID-19 are: infectious respiratory diseases caused by viruses and bacteria, such as the influenza virus or Legionella; allergic respiratory diseases, such as asthma and hypersensitivity pneumonitis (HP), caused mostly by bacteria, fungi, and particles containing animal proteins; and immunotoxic respiratory or systemic diseases, such as organic dust toxic syndrome (ODTS), byssinosis, mycotoxicoses, and building-related disease, caused mostly by bacterial products, mainly endotoxins, and by fungal products primarily $(1 \rightarrow 3)-\beta$-d-glucans, mycotoxins, and volatile organic compounds (VOCs).

3) For HP, ODTS and byssinosis, four scenarios of possible interrelations between these comorbidities (CM) and COVID-19 have been postulated:

i) 'Triggering' - when infection with SARS-CoV-2 triggers severe CM after bioaerosol exposure. 
ii) 'Reverse triggering' - when exposure to bioaerosol exacerbates the symptomless or mild course of COVID-19 and evokes a severe disease.

iii) Mutual exacerbation of mixed disease (COVID-19 vs. $\mathrm{CM})$.

iv) Co-existence of severe or symptomless/mild COVID-19 with CM without exacerbation (with a low possibility).

4) A list of occupations in which a risk of COVID-19 exists as the result of exposure to SARS-CoV-2 bioaerosol, or to bioaerosols which may exacerbate this disease, comprises by now 11 groups, of which the most endangered are: health care workers, social workers (in particular aged care facilities workers), breeders of fur animals, workers of meat and poultry processing facilities, and workers engaged in the processing and selling of seafood. Most probably, and mostly in the developing countries, agricultural workers are also at risk of COVID-19 of occupational origin; however, as yet this thesis needs to be documented by epidemiological studies. In each working environment, the risk of occupational COVID-19 is enhanced by easy airborne transmission of the SARS-CoV-2.

5) Considering an urgent need for identification of the primary source of COVID-19 which spread worldwide from Huanan Market in China, the authors put forward two hypotheses for the origin of the disease. The first assumes that a mild form of the present SARS-CoV-2 has been circulating for a long time in the Chinese population inhabiting the eastern part of the country, and mutated under the influence of as yet unknown factor(s) present in the Chinese seafood markets, probably component(s) of bioaerosols, into the virulent and highly contagious form known as the present SARS-CoV-2. This is similar to the scenario that the authors call 'Reverse triggering'. The second, much less probable hypothesis, assumes the inter-species transmission of the mutated virus from any other invertebrate marine animals present on the market, or from fish. In conclusion, identification of the origin of COVID-19 would help in halting the devastating pandemic.

\section{REFERENCES}

1. Domingo P, Mur I, Pomar V, Corominas H, Casademont J, de Benito $\mathrm{N}$. The four horsemen of a viral Apocalypse: The pathogenesis of SARS-CoV-2 infection (COVID-19). EBioMedicine 2020; 58: 102887.

2. Dhama K, Khan S, Tiwari R, Sircar S, Bhat S, Malik YS, et al. Coronavirus disease 2019-COVID-19. Clin Microbiol Rev. 2020; 33: e00028-20.

3. Zhang R, Li Y, Zhang AL, Wang Y, Molina MJ. Identifying airborne transmission as the dominant route for the spread of COVID-19. Proc Natl Acad Sci USA 2020; 117: 14857-14863. doi: 10.1073/ pnas. 2009637117

4. Huang C, Wang Y, Li X, Ren L, Zhao J, Hu Y, et al. Clinical features of patients infected with 2019 novel coronavirus in Wuhan, China. Lancet 2020; 395: 497-506.

5. Sierpiński R, Pinkas J, Jankowski M, Juszczyk G, Topór-Mądry R, Szumowski $Ł$. Occupational risks for SARS-CoV-2 infection: The Polish experience. Int J Occup Med Environ Health. 2020; 33(6): 1-9.

6. Hosoki K, Chakraborty A, Sur S. Molecular mechanisms and epidemiology of COVID-19 from an allergist's perspective. J Allergy Clin Immunol. 2020; 146: 285-299.

7. Liu S, Zhi Y, Ying S. COVID-19 and asthma: reflection during the pandemic. Clin Rev Allergy Immunol. 2020; 59: 78-88.

8. Yang J, Zheng Y, Gou X, Pu K, Chen Z, Guo Q, et al. Prevalence of comorbidities in the novel Wuhan coronavirus (COVID-19) infection: a systematic review and meta-analysis. Int J Infect Dis. 2020; 94: 91-95.

9. 24th Collegium Ramazzini statement: Prevention of work-related infection in the COVID-19 pandemic. Int J Occup Med Environ Health 2020; 33(4): 535-557.
10. Lacey J, Dutkiewicz J. Bioaerosols and occupational lung disease. J Aerosol Sci. 1994; 25: 1371-1404.

11. Dutkiewicz J, Cisak E, Sroka J, Wójcik-Fatla A, Zając V. Biological agents as occupational hazards - selected issues. Ann Agric Environ Med. 2011; 18: 286-293.

12. Mackiewicz B, Skórska C, Dutkiewicz J. Relationship between concentrations of microbiological agents in the air of agricultural settings and occurrence of work-related symptoms in exposed persons. Ann Agric Environ Med. 2015; 22: 473-477.

13. Dutkiewicz J. Biological agents of occupational hazard in agriculture and forestry. Ubezpieczenia w Rolnictwie, Materiały i Studia, Kwartalnik. 2017; 63: 7-37 (in Polish).

14. Górny RL, Dutkiewicz J. Evaluation of microorganisms and endotoxin levels of indoor air in living rooms occupied by cigarette smokers and non-smokers in Sosnowiec, Upper Silesia, Poland. Aerobiologia. 1998; 14: 235-239.

15. Dutkiewicz J, Tucker J, Burrell R, Olenchock SA, Schwegler-Berry D, Keller III GE, et al. Ultrastructure of the endotoxin produced by Gram-negative bacteria associated with organic dusts. System Appl Microbiol. 1992; 15: 474-485.

16. Dutkiewicz J, Krysińska-Traczyk E, Skórska C, Sitkowska J, Prażmo Z., Urbanowicz B. Exposure of agricultural workers to airborne microorganisms and endotoxin during handling of various vegetable products. Aerobiologia. 2000; 16: 193-198.

17. Burrell R. Immunotoxic reactions in the agricultural environment. Ann Agric Environ Med. 1995; 2: 11-20.

18. Samson RA, Flannigan B, Flannigan ME. et al. Health Implications of Fungi in Indoor Environments. Elsevier, Amsterdam 1994.

19. Górny RL, Reponen T, Willeke K, Schmechel D, Robin D, Robin E, Boissier M, et al. Fungal fragments as indoor air contaminants. Appl Environ Microbiol. 2002; 68: 3522-3531.

20. Dutkiewicz J. Biological agents. In: Koradecka D (Ed). Handbook of Occupational Safety and Health, pp. 385-400. CRC Press, Taylor \& Francis Group, Boca Raton 2010.

21. Frazier CA (Ed). Occupational Asthma. Van Nostrand, New York 1980.

22. Lopata AL, O’Hehir RE, Lehrer SB. Shellfish allergy. Clin Exp Allergy. 2010; 40(6): 850-858.

23. Jeebhay MF, Robins TG, Lehrer SB, Lopata AL. Occupational seafood allergy: a review. Occup Environ Med. 2001; 58: 553-562.

24. Griffin P, Crook B, Lacey J, Topping MD. Airborne scampi allergen and scampi peelers asthma. In: Griffiths WD (Ed): Aerosols: their Generation, Behaviour and Application. Aerosol Society Second Conference, pp. 347-352. The Aerosol Society, London 1988.

25. Dutkiewicz J (Ed). Biological Hazards in Agriculture. Institute of Rural Heath, Lublin 1998 (in Polish).

26. Bengoechea JA, Bamford CGG. SARS-CoV-2, bacterial co-infections, and AMR: the deadly trio in COVID-19? EMBO Mol Med. 2020; 12: e12560.

27. Mapp C, Boschetto P, Miotto D, De Rosa E, Fabbri LM. Mechanisms of occupational asthma. Ann Allergy Asthma Immunol. 1999; 83: 645-664.

28. Wild LG, Lopez M. Occupational asthma caused by high-molecularweight substances. Immunol Allergy Clin North Am. 2003; 23: 235-250.

29. Morais-Almeida M, Pité H, Aguiar R, Ansotegui I, Bousquet J. Asthma and the coronavirus disease 2019 pandemic: a literature review. Int Arch Allergy Immunol 2020; 181: 680-688.

30. Centers for Disease Control and Prevention. Coronavirus disease 2019 (COVID-19). 2020. Available at: https://edubirdie.com/blog/people-atincreased-risk-for-severe-illness. Accessed October 1, 2020.

31. Abrams EM, Jong GW, Connie L. Yang CL. Asthma and COVID-19. CMAJ 2020; 192:E551. doi: 10.1503/cmaj.200617

32. Jackson DJ, Busse WW, Bacharier LB, Kattan M, O’Connor GT, Wood RA, et al. Association of respiratory allergy, asthma and expression of the SARS-CoV-2 receptor. J Allergy Clin Immunol. 2020; 146(1): 203-206.e3. doi: 10.1016/j.jaci.2020.04.009

33. Lovinsky-Desir S, Deshpande DR, De A, Murray L, Stingone JA, Chan A, et al. Asthma among hospitalized patients with COVID-19 and related outcomes. J Allergy Clin Immunol. 2020; 6: S0091-6749(20)31100-3. doi: 10.1016/j.jaci.2020.07.026

34. Chhiba KD, Patel GB, Vu THT, Chen MM, Guo A, Kudlaty E. Prevalence and characterization of asthma in hospitalized and nonhospitalized patients with COVID-19. J Allergy Clin Immunol. 2020; 146: 307-314.

35. Chang YS. COVID-19 and allergy. Asia Pac Allergy. 2020; 10(3): e34.

36. Wang JY, Pawankar R, Tsai HJ, Wu SL, Kuo WS. COVID-19 and asthma, the good or the bad? Allergy 2020; 3: 10.1111/all.14480. doi: 10.1111/all.14480 
37. Peters MC, Sajuthi S, Deford P, Christenson S, Rios CL, Michael T. Montgomery MT, et al. COVID-19-related genes in sputum cells in asthma. Relationship to demographic features and corticosteroids. Am J Respir Crit Care Med. 2020; 202(1): 83-90.

38. Sajuthi SP, DeFord P, Jackson ND, Montgomery MT, Everman JL, Rios $\mathrm{CL}$, et al. Type 2 and interferon inflammation strongly regulate SARS CoV-2 related gene expression in the airway epithelium. bioRxiv. 2020; 2020.04.09.034454. doi: 10.1101/2020.04.09.034454

39. Radzikowska U, Ding M, Tan G, Zhakparov D, Peng Y, Wawrzyniak P, et al. Distribution of ACE2, CD147, CD26 and other SARS-CoV-2 associated molecules in tissues and immune cells in health and in asthma, COPD, obesity, hypertension, and COVID-19 risk factors. Allergy 2020. doi: 10.1111/ALL.14429

40. Williamson EJ, Walker AJ, Bhaskaran K, Bacon S, Bates C, Morton CE et al. Factors associated with COVID-19-related death using OpenSAFELY. Nature. 2020; 584(7821): 430-436. doi: 10.1038/s41586-020-2521-4

41. Wark PAB, Ramsahai JM, Pathinayake P, Malik B, Bartlett NW. Respiratory viruses and asthma. Semin Respir Crit Care Med. 2018; 39(1): 45-55.

42. Nogueira R, Melo N, Novais e Bastos H, Martins N, Delgado L, Morais A, Mota PC. Hypersensitivity pneumonitis: Antigen diversity and disease implications. Pulmonology. 2019, 25(2): 97-108.

43. Selman M, Pardo A, King TE Jr. Hypersensitivity pneumonitis: insights in diagnosis and pathobiology. Am J Respir Crit Care Med. 2012; 186(4): 314-324.

44. Malmberg P, Rask-Andersen A, Höglund S, Kolmodin-Hedman B, Read Guernsey J. Incidence of organic dust toxic syndrome and allergic alveolitis in Swedish farmers. Int Arch Allergy Appl Immunol. 1988; 87(1): 47-54

45. Quirce S, Vandenplas O, Campo P, Cruz MJ, de Blay F, Koschel D, et al. Occupational hypersensitivity pneumonitis: an EAACI position paper Allergy. 2016; 71(6): 765-779.

46. Milanowski J, Dutkiewicz J, Potoczna H, Kuś L, Urbanowicz B. Allergic alveolitis among agricultural workers in eastern Poland: A study of twenty cases. Ann Agric Environ Med. 1998; 5: 31-43.

47. Lemieszek M, Chilosi M, Golec M, Skórska C, Huaux F, Yakoub Y, et al. Mouse model of hypersensitivity pneumonitis after inhalation exposure to different microbial antigens associated with organic dusts. Ann Agric Environ Med. 2011; 18: 159-168.

48. Lemieszek MK, Chilosi M, Golec M, Skórska C, Dinnyes A, Mashayekhi $\mathrm{K}$, et al. Age influence on hypersensitivity pneumonitis induced in mice by exposure to Pantoea agglomerans. Inhal Toxicol. 2013, 25: 640-650.

49. Dutkiewicz J, Mackiewicz B, Lemieszek MK, Golec M, Skórska C, GóraFlorek A, Milanowski J. Pantoea agglomerans: a mysterious bacterium of evil and good. Part. II. - Deleterious effects: Dust-borne endotoxins and allergens - focus on grain dust, other agricultural dusts and wood dust. Ann Agric Environ Med. 2016; 23: 6-29.

50. Mackiewicz B, Dutkiewicz J, Siwiec J, Kucharczyk T, Siek E, Wójcik-Fatla A, et al. Acute hypersensitivity pneumonitis in woodworkers caused by inhalation of birch dust contaminated with Pantoea agglomerans and Microbacterium barkeri. Ann Agric Environ Med. 2019; 26(4): 644-655.

51. Sanchez-Gonzalez MA, Moskowitz D, Issuree PD, Yatzkan G, Rizvi SA, Day K. A pathophysiological perspective on COVID-19's lethal complication: from viremia to hypersensitivity pneumonitis-like immune dysregulation. Infect Chemother. 2020; 52(3): e31.

52. Dakhama A, Hegele RG, Laflamme G, Israël-Assayag E, Cormier Y. Common respiratory viruses in lower airways of patients with acute hypersensitivity pneumonitis. Am J Respir Crit Care Med. 1999; 159: $1316-1322$.

53. Cormier Y, Israël-Assayag E, Fournier M, Tremblay GM. Modulation of experimental hypersensitivity pneumonitis by Sendai virus. J Lab Clin Med. 1993; 121(5): 683-688.

54. Cormier Y, Tremblay GM, Fournier M, Israël-Assayag E. Long-term viral enhancement of lung response to Saccharopolyspora rectivirgula. Am J Respir Crit Care Med. 1994; 149: 490-494.

55. Cormier Y, Israël-Assayag E. The role of viruses in the pathogenesis of hypersensitivity pneumonitis. Curr Opin Pulm Med. 2000; 6(5): 420-423.

56. Gudmundsson G, Monick MM, Hunninghake GW. Viral infection modulates expression of hypersensitivity pneumonitis. J Immunol. 1999; 162: 7397-7401.

57. Kuś L. Allergic alveolitis after exposure to antigens occurring in grain dust in the light of own clinical and experimental investigations. Dissertation for the degree of Dr habil. Medical University, Lublin 1980 (in Polish)

58. Lemieszek MK, Rzeski W, Golec M, Mackiewicz B, Zwoliński J, Dutkiewicz J, Milanowski J. Pantoea agglomerans chronic exposure induces epithelial-mesenchymal transition in human lung epithelial cells and mice lungs. Ecotoxicol Environ Saf. 2020: 194: 110416.

59. Ochsner SA, McKenna NJ. A transcriptional regulatory atlas of coronavirus infection of human cells. BioRxiv Preprint. doi: https:// doi.org/10.1101/2020.04.24.059527. Version posted April 27, 2020.

60. Stewart CA, Gay CM, Ramkumar K, Cargill KR, Cardnell RJ, Nilsson $\mathrm{MB}$, et al. SARS-CoV-2 infection induces EMT-like molecular changes, including ZEB1-mediated repression of the viral receptor ACE2, in lung cancer models. BioRxiv Preprint. doi: 10.1101/2020.05.28.1222912020 Version posted May 29, 2020.

61. Song YG, Shin HS. COVID-19, a clinical syndrome manifesting as hypersensitivity pneumonitis. Infect Chemother. 2020; 52(1): 110-112.

62. Von Essen S, Robbins RA, Thompson AB, Rennard SI. Organic dust toxic syndrome: an acute febrile reaction to organic dust exposure distinct from hypersensitivity pneumonitis. J Toxicol Clin Toxicol. 1990; 28(4): 389-420.

63. Petruk G, Puthia M, Petrlova J, Strömdahl A-C, Kjellström S, Schmidtchen A. SARS-CoV-2 Spike protein binds to bacterial lipopolysaccharide and boosts proinflammatory activity. bioRxiv DOI: https://doi.org/10.1101/2020.06.29.175844.

64. Nain N, Hinder F, Gong JH, Schmidt A, Bender A, Sprenger H, Gemsa D. Tumor necrosis factor-alpha production of influenza A virusinfected macrophages and potentiating effect of lipopolysaccharides. J Immunol. 1990: 145(6): 1921-1928.

65. Dutkiewicz J, Skórska C, Burrell R, Szuster-Ciesielska A, Sitkowska J. Immunostimulative effects of repeated inhalation exposure to microvesicle-bound endotoxin of Pantoea agglomerans. Ann Agric Environ Med. 2005; 12: 289-294.

66. Mueller M, Lindner B, Kusumoto S, Fukase K, Schromm AB, Seydel U. Aggregates are the biologically active units of endotoxin. J Biol Chem 2004; 279(25): 26307-26313.

67. Yang J, Kim Y-K, Kang TS, Jee Y-K, Kim Y-Y. Importance of indoor dust biological ultrafine particles in the pathogenesis of chronic inflammatory lung diseases. Environ Health Toxicol. 2017; 32: e2017021.

68. Yang J, Kim EK, Park HJ, McDowell A, Kim Y-K. The impact of bacteriaderived ultrafine dust particles on pulmonary diseases. Exp Molec Med 2020; 52: 338-347.

69. Kim YY, Joh JS, Lee JY. Importance of microbial extracellular vesicle in the pathogenesis of asthma and chronic obstructive pulmonary disease and its diagnostic potential. Asia Pac Allergy. 2020; 10(3): e25.

70. Rylander R. Bacterial toxins and etiology of byssionosis. Chest 1981; Suppl. 79: 34S-38S.

71. Rylander R. The role of endotoxin for reactions after exposure to cotton dust. Am J Ind Med. 1987; 12: 687-697.

72. Menon B, Mrigpuri P, Tiwari M, Raj P. Diffuse lung disease caused by cotton dust exposure. J Lung Pulm Respir Res. 2018; 5(6): 176-178.

73. Gangan SP. 'Textile workers' lung diseases make them vulnerable to Covid'. Hindustan Times, Mumbai, Jul 09, 2020.

74. Sorenson WG. Mycotoxins. Toxic metabolites of fungi. In: Murphy JW, et al. (Eds): Fungal Infection and Immune Response, pp. 469-491. New York, Plenum Press 1993.

75. Górny R. L. (Ed). Water Damage to Buildings and Their Microbiological Corrosion. Causes, Risks, Prevention and Remediation. Central Institute for Labour Protection, Warsaw 2010.

76. Rylander R, Persson K, Goto H, Yuasa K, Tanaka S. Airborne ?-1,3-glucan may be related to symptoms in sick buildings. Indoor Environ. 1992; 1: 263-267.

77. Hosseini MR, Reza Fouladi-Fard R, Aali R. COVID-19 pandemic and sick building syndrome. Indoor Built Environ. 2020; 0(0): 1-3. doi: $10.1177 / 1420326$ X20935644

78. Koh D. Occupational risks for COVID-19 infection. Occup Med. 2020; 70:3-5.

79. Eisen D. Employee presenteeism and occupational acquisition of COVID-19. Med J Aust. 2020; 13(3): 140-140.

80. Ministry of Health, Poland. Official data on COVID-19 among health care workers in Poland between 4.03.2020-2.11.2020. Announced: 3.11.2020. https: Iwww.medonet.pl (in Polish).

81. Morawska L, Tang JW, Bahnfleth W, Bluyssend PM, Boerstrae A, Buonanno G, et al. How can airborne transmission of COVID-19 indoors be minimised? Environ Internat. 2020; 142: 105832.

82. National Center for Farmworkers Health, Inc. COVID-19 in Rural America: Impact on Farms \& Agricultural Workers. Farmworker Health Factsheet, October 1, 2020.

83. Tuirán R., Roberts N. Farmworkers are among those at highest risk for COVID-19, studies show. PBS, Frontline July 21, 2020. https://www. pbs.org/wgbh/frontline/article/covid-19-farmworkers-among-highestrisk-studies-show/ 
84. Zhong Z-F, Huang J, Yang X, Peng J-L, Zhang X-Y, Hu Y, et al. Epidemiological and clinical characteristics of COVID-19 patients in Hengyang, Hunan Province, China. World J Clin Cases. 2020; 8(12): 2554-2565.

85. Oreshkova N, Molenaar RJ, Vreman S, Harders F, Oude Munnink BB, Hakze-van der Honing RW, et al. SARS-CoV-2 infection in farmed minks, the Netherlands, April and May 2020. Euro Surveill.2020; 25(23): pii=2001005. https://doi.org/10.2807/1560-7917.ES.2020.25.23.2001005

86. Enserink M. Coronavirus rips through Dutch mink farms, triggering culls. Public concerns rise as two workers catch the disease. Science 2020; 368(6496): 1169. doi: 10.1126/science.368.6496.1169

87. Anonymous. Netherlands terminates mink farming following COVID-19 outbreaks. CGTN, 03-Jul-2020 (press note).

88. Barsoe T, Heinrich M (Reuters Staff). Denmark to cull up to one million mink due to risk of coronavirus contagion. Reuters, Environment, October 2, 2020 (press note).

89. Dyal JW, Grant MP, Broadwater K, Bjork A, Waltenburg MA, Gibbins JD, et al. COVID-19 among workers in meat and poultry processing facilities - 19 States, April 2020. MMWR Morb Mortal Wkly Rep. 2020; 69(18 557): 557-561.

90. Middleton J, Reintjes R, Lopes H. Meat plants-a new front line in the COVID-19 pandemic. These businesses failed in their duty to worker and the wider public health. BMJ 2020; 370: m2716. doi: 10.1136/bmj. $\mathrm{m} 2716$.

91. Halliday J. Over 450 cases of COVID-19 reported at food factories in England and Wales. Guardian 2020, Jun 25 (press note), https://www. theguardian.com/uk-news/2020/jun/25/over-450-covid-19-casesreported-at-food-factories-in-england-and-wales.

92. Anonymous. A Wuhan shrimp seller identified as coronavirus 'patient zero'. The Economic Times, Word News, March 30, 2020 (press note).

93. Bertelsen R, Svanes $\varnothing$, Hollund BE, Madsen AM, Sigsgaard T, Aasen T, Svanes C. Organic dust toxic syndrome caused by occupational exposure to shrimpshell powder. Eur Respir J. 2015; 46: PA4098. doi: 10.1183/13993003.congress-2015.PA4098

94. Craze M. Ecuador shrimp capital is coronavirus epicenter. Undercurrent News - seafood business news from beneath the surface, April 20 2020 (press note). https://www.undercurrentnews.com/terms-andconditions.

95. Walsh M, Simin W. The mystery link between China's Covid-19 outbreaks and seafood. CX Daily Briefing, Caixin, Jul 28, 2020 (press note).

96. Anonymous, COVID-19 outbreaks in Wuhan, Beijing and Dalian share certain similarities. CGTN, Health 30-Jul-2020 (press note).

97. Nishiura H, Linton NM, Akhmetzhanov AR. Initial cluster of novel coronavirus (2019-nCoV) infections in Wuhan, China is consistent with substantial human-to-human transmission. J Clin Med. 2020; 9: 488. doi: $10.3390 /$ jcm 9020488

98. Cowley JA. Nidoviruses of Fish and Crustaceans. In: Aquaculture Virology. Elsevier Inc. 2016, 443-472. http://dx.doi.org/10.1016/B9780-12-801573-5.00032-2

99. Ziebuhr J, Bayer S, Cowley JA, Gorbalenya AE. The 3C-like proteinase of an invertebrate Nidovirus links Coronavirus and Potyvirus homologs. J Virol. 2003; 77(2): 1415-1426. 